\title{
Current Publications List - Feb. 1969
}

\section{GENERAL}

British Columbia Forest Service, 1968. Forest Research Review. Dept. Lands, Forests, and Water Resources, Victoria, B. C. 98 pp.

Canada, Dept. Forestry and Rural Development. 1968. Lower St. Lawrence, Gaspe, and Isles de la Madeleine area of Quebec, Federal Provincial Rural Development Agreement. Ottawa. 61 pp.

Cumming, H. G., 1968. Deer Hunt in Ontario, 1967. Ontario Dept. Lands and Forests, Toronto. $17 \mathrm{pp}$.

Picard, G. and A. Juneau. 1968. A Sociological study of agricultural change in the pilot region (BAEQ) ARDA Condensed report. CR-15 Can. Dept. of For. and Rural Dev. Ottawa. 15 pp.

Rothacher, J. S. and T. B. Glazebrook. 1968. Flood Damage in the National Forests of Region 6. Pacific Northwest Forest and Range Experiment Station. USFS. Portland Ore. $20 \mathrm{pp}$.

Whittaker, J. C. 1968. Land Leasing: an aid to developing outdoor recreation enterprises in Indiana, Kentucky and Ohio. Res. Pap No. NE-113. Northeastern FES. Upper Darby $\mathrm{Pa} .12 \mathrm{pp}$.

\section{MANAGEMENT}

Anderson, H. E. 1968. Fire spread and flame shape. Fire Technology 4(1):57-58. USFS Intermountain FRES No. R74. Ogden Utah.

Anderson, W. C. 1968. Factors influencing North Carolina landowners to practice forestry. USFS Res. Pap. SO-33. Southern FES. New Orleans La. 18 pp.

Bonnor, G. M. 1968. Stem diameter estimates from crown width and tree height. Reprint
Commonwealth Forestry Review 47(1) No. 131 March 1968. Can. Dept. For. and Rural Dev. Ottawa. 6 pp.

Brickell, J. E. 1968. A method for constructing site index curves from measurements of tree age and height . . . its application to inland Douglas-fir. Res. Pap. INT-47. Intermountain FRES. 23 pp.

Crouch, G. L. 1968. Spring season deer browsing of Douglas-fir on the Capitol Forest in Western Washington. USFS Res. Note PNW*84 Pacific Northwest FRES. Portland Ore. $8 \mathrm{pp}$.

Curtis, J. D. 1968. What do you mean, "Site preparation"? USFS Res. Note INT-15. Intermountain FRES. Ogden Utah. 8 pp.

DeBoo, R. F. and V. Hildahl. 1968. Aerial spraying for control of the jack-pine budworm in Manitoba. Repr. The Manitoba Entomologist Vol. 1 pp. 21-26. Can. Dept. F\&RD. Ottawa.

Drouin, J. A. and W. J. Turnock. 1968. Occurence of the eastern Larch Beetle in Manitoba and Saskatchewan. Repr. The Manitoba Entomologist Vol. 1 pp. 18-20. Can. Dept. F.\&R.D. Ottawa.

Durzan, D. J. and S. M. Lopushanski. 1968. Free and bound amino acids of spruce budworm larvae feeding on balsam fir and red and white spruce. Repr. Journal of Insect Physiology. Vol. 14 pp. 1485-1497. Can. Dept. F\&RD Ottawa.

Drysdale, R. J. 1968. An analysis of the 1967 detection evaluation and improvement programs Kenora and Fort Frances Districts. Ont. Dept. Lands and Forests. Toronto. 116 pp. 
Hard, J. S. and D. C. Schmiege. 1968. The Hemlock Sawfly in Southeast Alaska. USFS Res. Pap. PNW-65. Pacific Northwest FRES. 11 pp.

Hirsch, S. N., R. L. Bjarnsoen, F. H. Madden and R. A. Wilson. 1968. Project fire scan fire mapping final report, April 1962 to December 1966 (work unit 2521A). USFS Res. Pap. INT-49. Intermountain FRES. Ogden Utah. 49 pp.

Jeffrey, W. W., L. A. Bayrock, L. E. Lutwick and J. F. Dormaar. 1968. Land-vegetation typology in the Upper Oldman River Basin, Alta. Publ. 1202. Can. Dept. For. and Rural Dev. 45 pp.

Kiil, A. D. 1968. Weight of the fuel complex in 70 year old Lodgepole pine stands of different densities. Publ. 1228. Canada Dept. For. and Rurai Dev. Ottawa. 9 pp.

Kingsley, N. P. and J. E. Barnard. 1968. The timber resources of Vermont. USFS Res. Bull. NE-12. Northeastern FES. 117 pp.

Kourtz, P. H. 1968. Resource allocation for forest fire control. Publ. 1232. Can. Dept. For. and Rural Dev. Ottawa. 10 pp.

Leak, W. B., S. M. Filip, and D. S. Solomon. 1968. Rates of value increase for yellow birch in New England. USFS Res. Pap. NE-120. Northeastern FES, Upper Darby Pa.

Mactavish, J. S. 1968. L'évaluation des dommages causés par les incendies aux peuplements forestiers arrivés à maturité. Publ. 1162F. Can. Dept. For. and Rural Dev. Ottawa. 32 pp.

McCormack, R. J. 1968. Guidelines for mapping land capability for forestry. ARDA Can. Land Inventory. Can. Dept. For. and Rural Dev. 20 pp.

Pech, G. 1968. The association between atmospheric humidity and fuel moisture. Publ. 1230. Can. Dept. For. and Rural Dev. Ottawa. 18 pp.

Poetschke, L. E. 1968. Regional planning for depressed rural areas: The Canadian experience. Can. Dept. For. and Rural Dev. 12 pp.

Stage, A. R., R. C. Dodge and J. E. Brickell. 1968. NETVSL - a computer program for calculation of tree volumes with interior defect. USFS Res. Pap. INT-51. Intermountain FRES. 30 pp.

Van Wagner, C. E. 1968. Fire behaviour mechanisms in a red pine plantation: field and laboratory evidence. Publ. 1229. Can. Dept. For, and Rural Dev. Ottawa. 30 pp.

Wagar, J. A. and J. F. Thalheimer. 1968. Computer programs for weighting length-of-stay and other visitor characteristics. USFS Res. Note INT-79. Intermountain FRES. 12 pp.

Westby, R. L., A. H. Aldred, \& L. Sayn-Wittgenstein. 1968. The potential of large-scale air photographs and radar altimetry in land evaluation. Repr. Land Evaluation, Australia. pp. 376-383. Can. Dept. For. and Rural Dev. Ottawa.

\section{SILVICULTURE}

Blum, B. M. and C. B. Gibbs, 1968. Variation of sugar maple sap yield and its influence on experimental design. USFS Res. Pap. NE-108. Northeastern FES, Upper Darby Pa. 8 pp.
Blum, B. M. and M. R. Koeling. 1968. Effect of vacuum pumping on lateral movement of sap in the maple tree bole. USFS Res. Pap. NE-107. Northeastern FES. 7 pp.

Blum, B. M. and M. R. Koeling. 1968. Vacuum pumping increases sap yields from sugar maple trees. USFS Res. Pap. NE-106. Northeastern FES. 14 pp.

Brace, L. G. 1968. Improvement cut in pine mixedwoods. Publ. 1235 Can. Dept. For. and Rural Dev. Ottawa. 12 pp.

Croker, T. C. 1968. Longleaf pine regeneration in Mountain and piedmont provinces of Alabama. USFS Res. Note SO-76. Southern FES, New Orleans La. 3 pp.

Franklin, J. F. 1968. Cone production by upper slope conifers. USFS Res. Pap. PNW-60 Pacific Northwest FRES. Portland, Ore. $21 \mathrm{pp}$.

Grano, C. X. and H. C. Grigsby. 1968. Spraying southern pines not practical for tip-moth control. USFS Res. Note SO-77. Southern FES. 2 pp.

Grisez, T. J. 1968. Growth and development of older plantations in northwestern Pennsylvania. USFS Res. Pap. NE-104. Northeastern FES, Upper Darby Pa. $40 \mathrm{pp}$.

Herrick, O. W. and J. E. Morse. 1968. Investment analysis of stand improvement and reforestation opportunities in Appalachian forests. USFS Res. Pap. NE-111. Northeastern FES. 43 pp.

Houston, D. R. and H. G. Eno. 1968. Use of soil fumigants to control spread of Fomes annosus. USFS Res. Pap. NE-123. Northeastern FES. Upper Darby $\mathrm{Pa}$.

Kearney, N. S. and F. T. Bonner. 1968, Sweetgum seed production on soils in central Mississippi. USFS Res. Note SO-75. Southern FES, New Orleans, La. 2 pp.

Krueger, K. W. 1968. Investigations of shingle tow packing material for conifer seedlings. USFS Res. Pap. PNW-63. Pacific Northwest FRES, Portland Ore. $10 \mathrm{pp}$.

Mader, D. L. and H. W. Lull. 1968. Depth, weight, and water storage of the forest floor in white pine stands in Massachusetts. USFS Res. Pap. NE109. Northeastern FES. 33 pp.

Roche, L. 1968. The value of short term studies in provenance research. Repr. Commonwealth Forestry Rev. Vol. 47(1) No. 131. March 1968. pp. 14-26. Can. Dept. For. and Rural Dev. Ottawa.

Russell, T. E. and A. L. Mignery, 1968. Direct seeding pine in Tennessee's highlands. USFS Res. Pap. SO-31. Southern FES 22 pp.

Tew, R. K. 1968. Properties of soil under aspen and adjacent herb shrub cover. USFS Res. Note INT78. Intermountain FRES 4 pp.

Trimble, G. R. 1968. Form recovery by understory sugar maple under uneven-aged management. USFS Res. Note NE-89. Northeastern FES, Upper Darby $\mathrm{Pa}$.

Williams, C. B. 1968. Seasonal height growth of upper slope conifers USFS Res. Pap. PNW-62. Pacific Northwest FRES $7 \mathrm{pp}$. 
Austin, J. W. 1968. Production, prices, employment and trade in the Northwest forest industries, Second quarter 1968. USFS Pacific Northwest FRES. Portland Ore. 25 pp.

Binkley, V. W. and H. H. Lysons. 1968. Planning single span skylines USFS Res. Pap. PNW-66. Pacific Northwest FRES. 10 pp.

Beltz, R. C. and J. F. Christopher. 1968. Pole and piling production in the midsouth. USFS Res. Bull. SO-13. Southern FES $17 \mathrm{pp}$.

Cech, M. Y. 1968. Dimensional stabilization of tree cross sections with polyethylene glycol. Publ. 1224 Can. Dept. For. and Rural Dev. Ottawa. $49 \mathrm{pp}$.

Cost, N. D. 1968. Southern pulpwood production, 1967. Southern and Southeastern Forest Experiment Stations. 23 pp.

Koch, P. 1968. Wood Machining abstracts 1966 and 1967. USFS Res. Pap. SO-34. Southern FES. 38 pp.

\section{reviews}

\section{Pests and Diseases of}

\section{Forest Plantation Trees}

by F. G. Browne, Oxford University Press, 70 Wynford Drive, Don Mills, Ontario. 1330 pp., $\$ 45.00$

This book brings together, in the form of an annotated list, information on several thousand pests taken as a result of a resolution passed at the Eigth taken as a result of a resolution passed at the Eighth British Commonwealth Forestry Conference in 1962. The Conference recognized the dangers inherent in the indiscriminant importation of plantation material and urged Commonwealth countries to cooperate in the compilation of a list of potentially dangerous plantation pests and diseases. A circular inquiry was distributed to all members of the Commonwealth and the replies, together with a review of literature available to the author, provided the background information for this book.

The compilation is organized in to three parts. The first deals with animal pests, mainly insects, listed in alphabetical order with information on distribution, hosts, habits, and importance; the second treats diseases in the same manner; and the third lists the pests and diseases by tree hosts. The book concludes with a glossary of common names and an extensive bibliography.
Kingsley, N. P. and D. R. Dickson. 1969. Pulpwood production in the Northeast - 1967. USFS Res. Bull. NE-13. Northeastern FES.

Lucas, J. T. and W. B. Walin. 1968. The Dept. of Defence market for wooden pallets: 1966. Res. Pap. 1922. Northeastern FES.

Martens, D. G. 1968. Flooring costs: a comparison of the installation and maintenance costs for the three types of residential flooring USFS Res. Pap. NE-124. Northeastern FES.

Strobel, J. J. and W. B. Wallin. 1968. The unit-load explosion in the food industry - a study showing the importance of the wooden pallet in materials handling. USFS Res. Pap. NE-122 Northeastern FES, Upper Darby Pa.

Williams, D. L. and W. C. Hopkins. 1968. Converting factors for southern pine products. Bull. No. 626, Louisiana State Univ. Agricultural Expt. Sta. $89 \mathrm{pp}$.
Although limited in scope to the principal species occurring in the Commonwealth, the book provides a comprehensive coverage of many problems of interest to practising foresters, entomologists and pathologists. It will be a particularly valuable guide and a first reference source for inspection and control officers concerned with the accidental introduction of foreign pests on planting stock. One weakness in the compilation is that pests and disease organisms are not indexed by the countries in which they occur. This type of index would be most useful to importing countries and the author should consider this in any future edition.

The Commonwealth Forestry Institute and the author deserve the highest praise for their efforts in bringing together this extensive body of information under one cover. The book will no doubt become a standard reference in many forestry centres and research libraries around the world, particularly in those countries importing planting stock from Commonwealth areas.

$$
\text { R. M. Prentice. }
$$

